J. Clin. Chem. Clin. Biochem.

Vol. 20, 1982, pp. 791-798

\title{
Studies on Simultaneous Determination of Acetaminophen, Salicylic Acid and Salicyluric Acid in Biological Fluids by High Performance Liquid Chromatography
}

\author{
By S. M. Douidar ${ }^{1}$ ) and A. E. Ahmed \\ Department of Pathology and Department of Pharmacology and Toxicology \\ The University of Texas Medical Branch at Galveston, Galveston, TX
}

(Received February 17/June 30, 1982)

Summary: A rapid and sensitive high performance liquid chromatographic method was developed for separation and quantitation of acetaminophen, salicylic acid and salicyluric acid in human plasma and urine. The method involved ethyl acetate extraction of the three drugs from plasma or urine followed by evaporation of the organic solvent phase and dissolution of the residue in $100 \mu \mathrm{l}$ methanol. A $20 \mu \mathrm{l}$ aliquot was analysed on a reversed phase column using an isocratic system of $60 \mathrm{ml} / 1$ acetonitrile in $4 \mathrm{mmol} / 1$ phosphate buffer, $\mathrm{pH} 5.7$ as a mobile phase and a variable wave length UV detector set at $237 \mathrm{~nm}$. The procedure was used to determine the amounts of the three compounds in plasma and urine of two healthy volunteers who ingested $650 \mathrm{mg}$ of aspirin ${ }^{\circledR}$ followed one hour later by $650 \mathrm{mg}$ of acetaminophen.

\section{Untersuchungen zur simultanen Bestimmung von Acetaminophen, Salicylsäure und Salicylursäure in biologischen Flüssigkeiten mit Hochleistungsflüssigchromatographie}

Zusammenfassung: Zur Trennung und quantitativen Bestimmung von Acetaminophen, Salicylsäure und Salicylursäure im menschlichen Plasma und Harn wurde eine schnelle und empfindliche hochleistungsflüssigchromatographische Methode entwickelt. Die drei Pharmaka werden mit Ethylacetat aus Plasma oder Hatn extrahiert, das Lösungsmittel abgedunstet und der Rückstand in $100 \mu \mathrm{l}$ Methanol gelöst. Ein Aliquot von $20 \mu \mathrm{l}$ wird an einer ,reversed phase "-Säule mit einem isokratischen System von $60 \mathrm{ml} / 1$ Acetonitril in $4 \mathrm{mmol} / 1$ Phosphatpuffer pH 5,7 als mobiler Phase und einem UV.Detektor $(\lambda=237 \mathrm{~nm}$ ) analysiert.

Das Verfahren wurde zur Bestimmung der drei Verbindungen in Plasma und Harn zweier gesunder Probanden, die $650 \mathrm{mg}$ Aspirin ${ }^{\circledR}$ und eine Stunde später $650 \mathrm{mg}$ Acetaminophen eingenommen hatten, eingesetzt.

\section{Introduction}

Acetaminophen and salicylates are the most common drugs used as analgesics and antipyretics. Although these are supposed to be given singly, there are many commercial products available which contain both in a single dosage form. In order to achieve a rapid therapeutic effect without the risk of chronic salicylism, physicians prescribe these drugs in a combined, alternate dosage regimen.

Alteration of the mode of biotransformation of acetaminophen by other drugs has been well documented. Houston \& Levy (1) demonstrated that ascorbic acid, administered in conjunction with acetaminophen, significantly reduces the excretion rate of acetaminophen sulfate. Levy et al. (2) demonstrated that salicylamide competitively inhibits the glucuronidation and sulfate conjugation of acetaminophen.

\footnotetext{
1) Fellow from the Pediatric Department, Tanta University, Tarita, Egypt. Rèsearch supported by the Agency for International Development, U.S.A.
}

We hypothise that co-administration of acetaminophen and salicylates, especially for prolonged periods, may cause competitive inhibition of glucuronidation of acetaminophen. Saturation of this pathway may result in shunting to other pathways with formation of toxic metabolites of acetaminophen which may lead to hepatocellular death (3).

This potential hazard from combination of both drugs prompted us to develop a simple and rapid method for separation and quantitation of both drugs and their metabolites in biological fluids.

A number of spectrophotometric (5-7) methods used for detection and quantitation of these drugs, can detect only one drug when both are present. Also, they are insensitive and time consuming. Gas-liquid chromatographic methods have been used for determination and quantitation of acetaminophen $(8,9)$, and salicylates $(10,11)$. These methods are sensitive and specific, how- 
ever, chemical derivatisation is necessary. Hence, they are time consuming and require high technical experience.

High performance liquid chromatographic methods $(12-14)$ were used for determination of acetaminophen alone. Other HPLC methods (15-19) were used for determination of salicylic acid and/or salicyluric acid. There is only one HPLC method (20) that determined both acetaminophen and salicylic acid simultaneously. However, the close and short retention times of acetaminophen and salicylic acid (2.15 and $2.90 \mathrm{~min}$ respectively) prevented the complete separation of both compounds from each other and from other biological compounds.

We describe in this report a reliable method for simultaneous quantitative determination of acetaminophen, salicylic acid and salicyluric acid in plasma or urine using HPLC.

$\because 1$

\section{Materials and Methods}

\section{Apparatus}

A liquid chromatographic system (Waters Associates, Inc., Milford, Massachusetts 01757) consisted of models 6000A and M45 pumps, model 720 system controller, model 730 data module and an automatic sample injector model 710B "WISP" (Waters Intelligent Sample Processor). The effluent was monitored by UV variable wave length detector (Beckman model 155, Berkeley, California 94710). Separation was accomplished using a Waters $\mu$ Bondapak C18 column, $3.9 \mathrm{~mm}$ i. d. $\times 30 \mathrm{~cm}$ containing $10 \mu \mathrm{m}$ particles of octadecylsilane-bonded spherical silica. Water and solvents were filltered with Gelman $0.2 \mu \mathrm{m}$ filters and degassed under vaccum prior to use.

\section{Reagents}

Acetaminophen (4-acetamidophenol, 98\%), sodium salicylate (99\%) and salicyluric acid (o-hydroxyhippuric acid, $97 \%$ ) were purchased from Aldrich Chemical Company, Inc., (Milwaukee, Wisconsin 53233). Ethyl acetate (HPLC grade) was obtained from Fisher Scientific Company (Fair Lawn, New Jersey 07410). Acetonitrile (HPLC grade) was purchased from Burdic \& Jack= son Laboratories, Inc., (Muskegon, Michigan 49442). Other chemicals and reagents were of the highest purity available and were obtained from various commercial sources.

\section{Analy tical.procedures}

\section{Extraction}

$100 \mu$ of plasma or urine was diluted to $1.0 \mathrm{ml}$ with distilled water after adjusting $\mathrm{pH}$ of plasma to 2.0 and $\mathrm{pH}$ of urine to 5.0. Fifteen ml of ethyl acetate and $4 \mathrm{~g}$ sodium chloride were added to the plasma or urine in $40 \mathrm{ml}$ volume glass tube with a glass stopper. The tube was shaken vigorously on a shaking apparatus for $15 \mathrm{~min}$ then centrifuged for $10 \mathrm{~min}$ to separate the phases. Ten $\mathrm{ml}$ of the ethyl acetate phase were aspirated into a clean tube. The ethyl acetate was evaporated to dryness at $45^{\circ} \mathrm{C}$ under a gentle stream of nitrogen. The residue was dissolved in $100 \mu \mathrm{l}$ methanol and mixed thoroughly using a vortex. A $20 \mu \mathrm{l}$ aliquot was injected into the liquid chromatograph.

\section{HPLC analysis}

After several trials, optimal separation of the three compounds was accomplished by eluting with $60 \mathrm{ml} / 1$ acetonitrile in $4 \mathrm{mmol} / 1$ phosphate buffer, pH 5.7. The flow rate was set at $1 \mathrm{ml} / \mathrm{min}$.
The module chart speed was $1 \mathrm{~cm} / \mathrm{min}$. Absorbance was monitored at $237 \mathrm{~nm}$ and recorded on the data module. Quantitation of peak areas using external standard technique was carried out using the data module integrator. Internal standard was found unnecessary, because by repeatcd injections of the three compounds into HPLC, reproducible results to within $4 \%$ were constantly achieved, besides the simplicity and complete recovery of the extraction procedure.

\section{Standard curve of actaminophen, salicylic acid} and salicyluric acit in plasma and urine

Stock solution was prepared by dissolving 30 mig ôf each of acetaminophen, salicylic acid and salicyluric acid in $100 \mathrm{ml}$ distilled water. Working standards were prepared by making appropriate dilutions of the stock standard solution.

Different concentrations of each of the three compounds ranging from $5 \mathrm{mg} / 1$ to $50 \mathrm{mg} / \mathrm{l}$ were added to drug-free plasma and urine. Extraction for each sample was carried out as mentioned before. A standard curve was obtained by plotting the concentration of each sample against the peak area.

Urinary excretion of free acetaminophen, salicylic acid and salicyluric acid in man

Two healthy volunteers, 26 and 33 years old and weighing 163 and 136 pounds (ca. 74 and ca. $62 \mathrm{~kg}$ ) and with no hístory of drug intake in the twelve week period preceding the test were studied. Each volunteer was given an oral dose of $650 \mathrm{mg}$ of aspirin ${ }^{\circledR}$ ạfter an overnight fast. One hour later, each subject was given $650 \mathrm{mg}$ of acetaminophen. No food was allowed up to two hours after acetanininophen intake. Both volunteers were allowed to drink water and fruit juices to increase urine flow. Urine samples were collected from aspirin ${ }^{\circledR}$ administration every 1 to 2 hours up to 12 hours, and at 24 hours. Urine samples were filtered and $\mathrm{pH}$ and volume of each sample were determined. The samples were stored at $-30^{\circ} \mathrm{C}$ up till the time of analysis.

Plasma concentration of free acetaminophen, salicylic acid and salicyluric acid in man

Blood samples were taken every $15 \mathrm{~min}$ to 1 hour up to four hours following drug administration. Each blood sample was received in a heparinized test tube and centrifuged. Plasma was aspirated and stored at $-30^{\circ} \mathrm{C}$ up till the time of analysis.

\section{Results and Discusșion}

The objective of this report is to develop a simple and sensitive HPLC method for simultaneous separation and quantitation of acetaminophen, salicylic acid and its main metabolite salicyluric acid in biological fluids: Also, to evaluate previously reported methodology for these compounds $(10,12-19)$. The method of Miceli et al. (20), which was carried out only on plasma for simultaneous measurement of acetaminophen and salicylic acid lacks the complete separation of both compounds due to their close retention times ( 2.15 and $2.90 \mathrm{~min}$ ). The short retention times of both compounds prevent their cleâr separation from the bịological background when this procedure is applied to urine samples. In addition, this method did not describe salicyluric acid determination. The method developed in our laboratory is simplè, sensitive and can be applied for determination of both compounds and their metabolites in serum or uñne in subtherapeutic, therapeutic or toxic doses of each or both drugs. 


\section{Optimization of extraction efficiency}

\section{Extraction solvent}

Several solvents have been used for extraction of acetaminophen, salicylic acid and salicyluric acid. Levy \& Yamada (2) and others $(12,13)$ used diethyl ether for extraction of acetaminophen from plasma and urine while Rowland \& Riegelman (10) used the same solvent for extraction of salicylic acid from plasma. Levy \& Procknal (21) used ethylene dichloride for extraction of both salicylic acid and salicyluric acid from urine samples. Miceli et al. (20) used a solvent mixture of chloroform and isopropanol $1 / 1$ by volume for extraction of both acetaminophen and salicylic acid from serum. In an attempt to develop one method of extraction of the three compounds from plasma and urine simultaneously, we tried these solvents in addition to ethyl acetate. Data in table 1 show the extraction efficiency of these solvents to $10 \mathrm{mg} / \mathrm{l}$ of each of acetaminophen, salicylic acid and salicyluric acid added to drug-free plasma and urine. The same extraction procedure was applied for all'solvent systems used.

From plasma the extraction efficiency of ether for acetaminophen and salicyluric acid was found to be high, however, for salicylic acid it was low. This indicates that ether is not a good extraction solvent for salicylic acid contrary to an earlier report (10). Ethylene dichloride has a very low extraction efficiency for acetaminophen and it was found that its capability for extraction of both salicylic acid and salicyluric acid lies within $50-55 \%$. This may seem contradictory to the previously reported methods considering ethylene dichloride as an efficient extractor for these compounds. This can be explained by the difference in $\mathrm{pH}$ of the biological medium during extraction. Ethylene dichloride wàs used previously as an extraction solvent at very low $\mathrm{pH}$ (21) which allows more efficient extraction for salicylic acid and salicyluric acid. This low pH may be suitable for spectrophotometric methods but we observed in our HPLLC analysis that at this low pH other compounds were extracted and interfered with the com- pounds under study. The extraction efficiency of ethyl ace tate from plasma at $\mathrm{pH} 2$ was found to be high for the three compounds without interference by any of the biological compounds. Chloroform/isopropanol, $1 / 1$ by volume has a high extraction efficiency for acetaminophen, moderate for salicylic acid and low for salicyluric acid at this $\mathrm{pH}$ (tab. 1).

From urine ether can extract acetaminophen with a high efficiency at $\mathrm{pH} 5$ but it has a low extraction efficiency for salicylic acid at this $\mathrm{pH}$. Ethylene dichloride has a low extraction efficiency at $\mathrm{pH} 5$ for the three compounds. Ethyl acetate was found to have the highest extraction efficiency for these three compounds. Extraction from urine at $\mathrm{pH} 5$ was found unreliable for chloroform/isopropanol mixture due to interference by other compounds extracted with the test compounds. As shown in table 1, the extraction efficiency of ethyl acetate for the three compounds from plasma at $\mathrm{pH} 2$ ranges from 98 to $104 \%$. Recovery of acetaminophen, salicylic acid and salicyluric acid from urine at $\mathrm{pH} 5$ was $98 \%, 87 \%$ and $87 \%$ respectively.

\section{Effect of $\mathrm{pH}$ of the biological medium}

The $\mathrm{pH}$ of the biological medium affects to a great extent the solvent's extraction efficiency for these compounds. Our study indicates that salicylic acid and salicyluric acid are better extracted at a more acidic $\mathrm{pH}$. This is due to the minimum ionization of salicylic acid at a $\mathrm{pH}$ below its $\mathrm{pK}_{\mathrm{a}}$ (3.0). Acetaminophen extraction was found not to be greatly affected by changes in $\mathrm{pH}$. Data in table 2 show the extraction efficiency of ethyl acetate for the three compounds at $\mathrm{pH} 2$ and $\mathrm{pH} 5$. As shown the three compounds are completely extracted from plasma at $\mathrm{pH} 2$. Extraction at this $\mathrm{pH}$ can only be applied to plasma due to no interference from biological background. However, in urine, as shown in figure 1, extraction at $\mathrm{pH} 2$ is unreliable due to the interference by other compounds simultaneously extracted along with these compounds. Repeated extractions of known concentrations of the three compounds added to drug-

Tab. 1. Extraction efficiency (recovery, $\%, \bar{x} \pm s$ ) of various solvent systems for acetaminophen, salicylic acid and salicyluric acid from plasma (extraction at $\mathrm{pH} 2$ )) and urine (extraction at $\mathrm{pH} 5$ ).

* values obtained ạre unreliable due to interference by biological background. ** less than $1 \%$ recovery.

\begin{tabular}{|c|c|c|c|c|c|c|c|c|}
\hline & \multicolumn{8}{|c|}{ Reçovery (\%) } \\
\hline & \multicolumn{2}{|l|}{ Ether } & \multicolumn{2}{|c|}{ Ethylene dichloride } & \multicolumn{2}{|c|}{$\begin{array}{l}\text { Chloroform/Isopropanol } \\
1+1\end{array}$} & \multicolumn{2}{|c|}{ Ethyl acetate } \\
\hline & Plasma & Ưrine & Plasma & Urine & Plasma & Ưrine & Plasma & Urine \\
\hline $\begin{array}{l}\text { Acetaminophen } \\
(10 \mathrm{mg} / \mathrm{l})\end{array}$ & $99 \pm 4$ & $96 \pm 3$ & $15 \pm 4$ & $17 \pm 4$ & $93.7 \pm 4$ & $*$ & $98 \pm 2$ & $98 \pm 4$ \\
\hline $\begin{array}{l}\text { Salicylic acid } \\
(10 \mathrm{mg} / \mathrm{l})\end{array}$ & $34.7 \pm 5$ & $41.3 \pm 2$ & $55^{\circ} \pm 2$ & $5.3 \pm 2$ & $65.8 \pm 6$ & $*$ & $98 \pm 2$ & $87 \pm 4$ \\
\hline $\begin{array}{l}\text { Salicyluric acid } \\
(10 \mathrm{mg} / \mathrm{l})\end{array}$ & $107 \pm 6$ & $91 \pm 4$ & $52.4 \pm 3$ & $* *$ & $48.2 \pm 6$ & $*$ & $104 \pm 6$ & $87 \pm 6$ \\
\hline
\end{tabular}


Tab. 2. Effect of $\mathrm{pH}$ on the extraction efficiency of ethyl acetate for acetaminophen, salicylic acid and salicyluric acid from plasma. Data shown arc mean valucs $\pm S D$.

\begin{tabular}{llllll}
\hline & $\begin{array}{l}\text { Drug } \\
\text { added to plasma } \\
(\mathrm{mg} / \mathrm{l})\end{array}$ & $\begin{array}{l}\text { Amount extracted } \\
\text { at pH 2 } \\
(\mathrm{mg} / \mathrm{l})\end{array}$ & $\begin{array}{l}\text { Extraction } \\
\text { efficiency } \\
(\%)\end{array}$ & $\begin{array}{l}\text { Amount extracted } \\
\text { at pH 5 } \\
(\mathrm{mg} / \mathrm{l})\end{array}$ & $\begin{array}{l}\text { Extraction } \\
\text { efficiency } \\
(\%)\end{array}$ \\
\hline Acetaminophen & 10 & $9.8 \pm 0.2$ & $98 \pm 2$ & $9.8 \pm 0.6$ & $98 \pm 6$ \\
Salicylic acid & 10 & $9.8 \pm 0.2$ & $98 \pm 2$ & $8.7 \pm 0.3$ & $87 \pm 3$ \\
Salicyluric acid & 10 & $10.4 \pm 0.6$ & $104 \pm 6$ & $8.7 \pm 0.4$ & $87 \pm 4$ \\
\hline
\end{tabular}

free urine at different $\mathrm{pH}$ indicated that at $\mathrm{pH} 5$ extraction efficiency ranged from 87 to $98 \%$ for all compounds studied. Minimal interference by other biological materials was observed at this $\mathrm{pH}$. Interestingly, Miceli et al. reported (20) that they extracted acetaminophen and salicylic acid at plasma $\mathrm{pH}$ (7.4). At that $\mathrm{pH}$ salicylic acid is highly ionized and hence very weakly soluble in organic solvents.

\section{Optimization of the HPLC system condition}

\section{Effect of mobile'phase}

Different mobile phases have been reported for the separation and quantitation of these compounds individually or in combination. When we tried one of these mobile phases as (methanol $9 \mathrm{~g} / 1$ acetic acid; fractions $0.12 / 0.88)(22)$, a constant peak was observed having the same retention time as acetaminophen in the blank biological samples. Hence, it interfered with acetaminophen determination. Under this condition, salicylic acid and salicyluric acid have long retention times (tab. 3).
Tab. 3. Effect of mobile phase on the retention times of acetaminophen, salicylic acid and salicyluric acid.

\begin{tabular}{|c|c|c|c|c|}
\hline \multicolumn{2}{|l|}{ Mobile phase } & \multicolumn{2}{|c|}{$\begin{array}{l}\text { Retention time } \\
\text { (min) }\end{array}$} & \multirow[b]{2}{*}{$\begin{array}{l}\text { Acet- } \\
\text { amino- } \\
\text { phen }\end{array}$} \\
\hline $\begin{array}{l}\text { Solvent } \\
\text { (A) }\end{array}$ & $\begin{array}{l}\text { Solvent } \\
\text { (B) }\end{array}$ & $\begin{array}{l}\text { Sali- } \\
\text { cylic } \\
\text { acid }\end{array}$ & $\begin{array}{l}\text { Salicyl- } \\
\text { uric } \\
\text { acid }\end{array}$ & \\
\hline $\begin{array}{l}\text { Acetonitrile } \\
400 \mathrm{ml}\end{array}$ & $\begin{array}{l}2 \mathrm{~g} / \mathrm{1} \\
\text { Acetic acid } \\
600 \mathrm{ml}\end{array}$ & 6.7 & 4.7 & 3.4 \\
\hline $\begin{array}{l}\text { Methanol } \\
120 \mathrm{ml}\end{array}$ & $\begin{array}{l}9 \mathrm{~g} / \mathrm{l} \\
\text { Acetic acid } \\
880 \mathrm{ml}\end{array}$ & 32.7 & 23.3 & 8.2 \\
\hline Acetonitrile & $\begin{array}{l}4 \mathrm{mmol} / 1 \\
\text { Phosphate } \\
\text { buffer } \\
930 \mathrm{ml}\end{array}$ & 5.3 & 6.2 & 8.4 \\
\hline Acetonitrile & $\begin{array}{l}4 \mathrm{mmol} / \mathrm{l} \\
\text { Phosphate } \\
\text { buffer } \\
940 \mathrm{ml}\end{array}$ & 5.7 & 7.4 & 9.7 \\
\hline
\end{tabular}
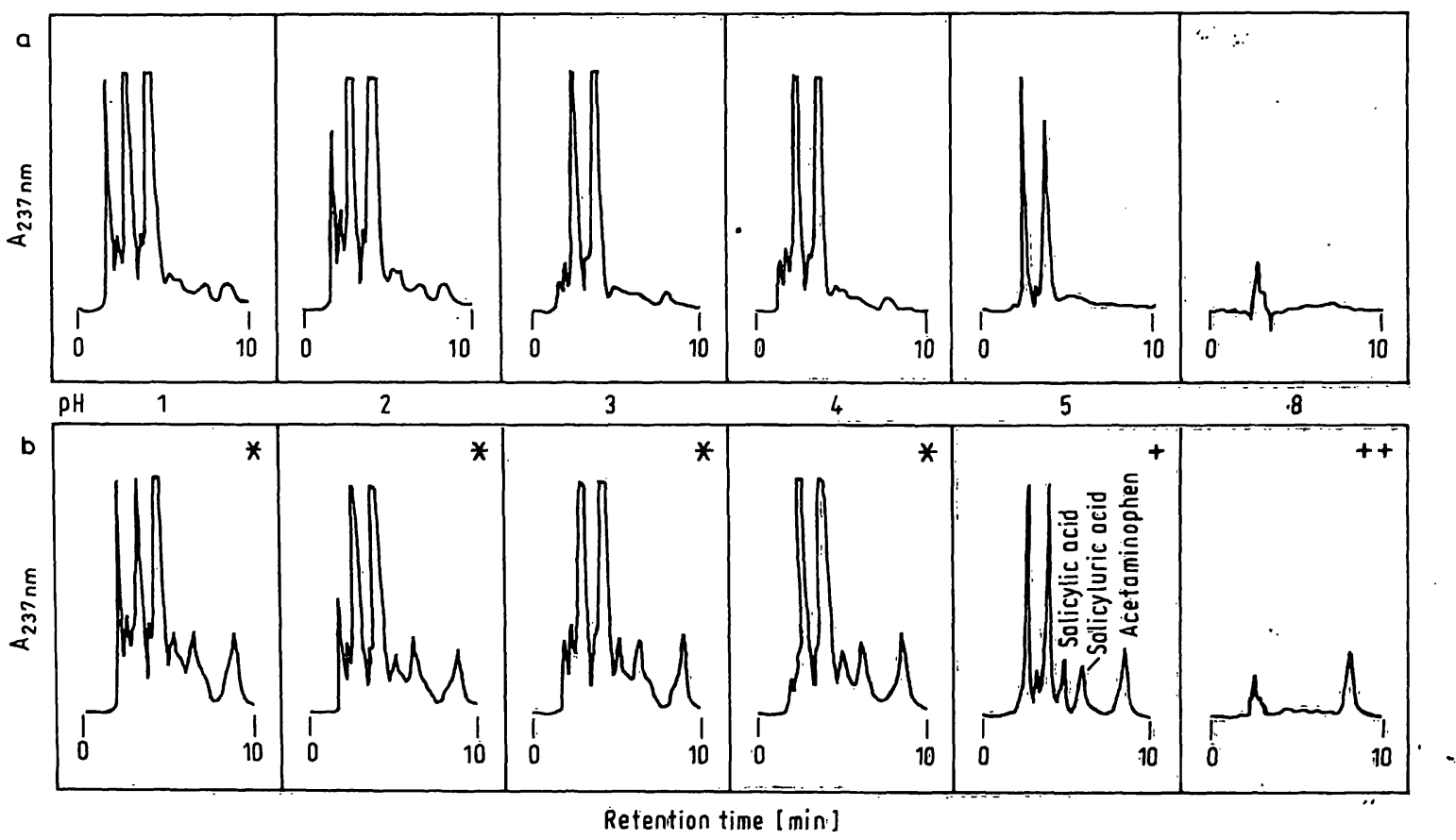

Fig. 1. Effect of $\mathrm{pH}$ on the extraction efficiency of ethyl acetate for acetaminophen, salicylic acid and salicyluric acid from urine. a) Blank urine extract b) Extract of urine, spiked with $10 \mathrm{mg} / \mathrm{l}$ each of acetaminophen, salicylic acid and salicyluric acid.

* values obtained are unreliable due to interference by other biological compounds.

+ extraction efficiencies for acetaminophen, salicylic acid and salicyluric acid are $98 \pm 2,87 \pm 4$ and $87 \pm 4$ respectively.

+ extraction efficiency for acetaminophen $97 \pm 3$, but for salicylic acid and salicyluric acid are less than $1 \%$. 
Using other mobile phases resulted in short retention times for all compounds and overlapping by biological background. For these reasons we tried to find a new mobile phase that could clearly separate these com. pounds without interference from other biological background. We found that $60 \mathrm{ml} / 1$ acetonitrile in $4 \mathrm{mmol} / \mathrm{l}$ phosphate buffer is an ideal mobile phase for this study. Data in table 3 illustrate different mobile phases used and the corresponding retention times of the three compounds studied.

\section{Effect of $\mathrm{pH}$ of mobile phase}

The retention time was found to be affected to a great extent by the change in $\mathrm{pH}$ of mobile phase. It was observed that the lower the $\mathrm{pH}$ the longer the retention times of the three compounds studied. Increasing the $\mathrm{pH}$ resulted in short retention times. Data in table 4 indicate that $\mathrm{pH} 5.7$ is optimal for separation of the three compounds. Slight alteration such as decimal increase or decrease in the $\mathrm{pH}$ was found to alter the retention times. Alteration of $\mathrm{pH}$ not only affects the retention time but also changes the time intervals between the individual compounds. Therefore separation is affected.

Tab. 4. Effect of $\mathrm{pH}$ of mobile phase (acetonitrile, $60 \mathrm{ml} / 1$ in $4 \mathrm{mmol} / 1$ phosphate buffer) on the retention times of acetaminophen, salicylic acid and salicyluric acid.

\begin{tabular}{llll}
\hline $\begin{array}{l}\text { pH } \\
\text { of mobile phase }\end{array}$ & $\begin{array}{l}\text { Retention time } \\
\text { (min) } \\
\text { Salicylic }\end{array}$ & $\begin{array}{l}\text { Salicyluric } \\
\text { acid }\end{array}$ & $\begin{array}{c}\text { Acet- } \\
\text { aminophen }\end{array}$ \\
\hline 5.7 & acid & 7.4 & 9.7 \\
5.0 & 5.7 & 10.9 & 11.2 \\
7.0 & 7.8 & 4.9 & 9.8 \\
\hline
\end{tabular}

\section{Effect of UV detector wave length}

The previous HPLC systems used different wave lengths for monitoring acetaminophen, salicylic acid or salicyluric acid. A wave length of $300 \mathrm{~nm}$ was used $(14,19)$ for monitoring salicylic acid. Wave lengths ranging from $247 \mathrm{~nm}$ to $254 \mathrm{~nm}$ were used $(12,13,20,22)$ for monitoring acetaminophen or salicylic acid or both. A wave length $237 \mathrm{~nm}$ was used (16) for monitoring both salicylic acid and salicyluric acid. In an áttempt to find the UV wave length which provided maximum sensitivity for these compounds, we compared the absorbance of each compound separately and in combination with the other two compounds at various wave lengths. The data in table 5 indicate that $237 \mathrm{~nm}$ is the most suitable wave length for monitoring the three compounds simultaneously. For acetaminophen the highest absorbance was observed at wave lengths $237 \mathrm{~nm}$ and $250 \mathrm{~nm}$, while the highest absorbances for salicylic acid and salicyluric acid were observed at $237 \mathrm{~nm}$. Hence, those previous methods which monitored these last two compounds at wave lengths other than $237 \mathrm{~nm}$ lacked the maximum sensitivity and probably underestimated these compounds especially at low concentrations.

The retention times for salicylic acid, salicyluric acid and acetaminophen were 5.7, 7.4 and $9.7 \mathrm{~min}$ respec- . tively. Figure 2a shows a chromatogram of a human plasma blank at $\mathrm{pH} 2$ after extraction by ethyl acetate. Figure $2 b$ shows a chromatogram of a human plasma blank spiked with $10 \mu \mathrm{g}$ each of acetaminophen, salicylic acid and salicyluric acid and extracted as described before. Figure $2 \mathrm{c}$ shows a chromatogram of a human plasma sample $1.5 \mathrm{~h}$ after $650 \mathrm{mg}$ of aspirin and $0.5 \mathrm{~h}$
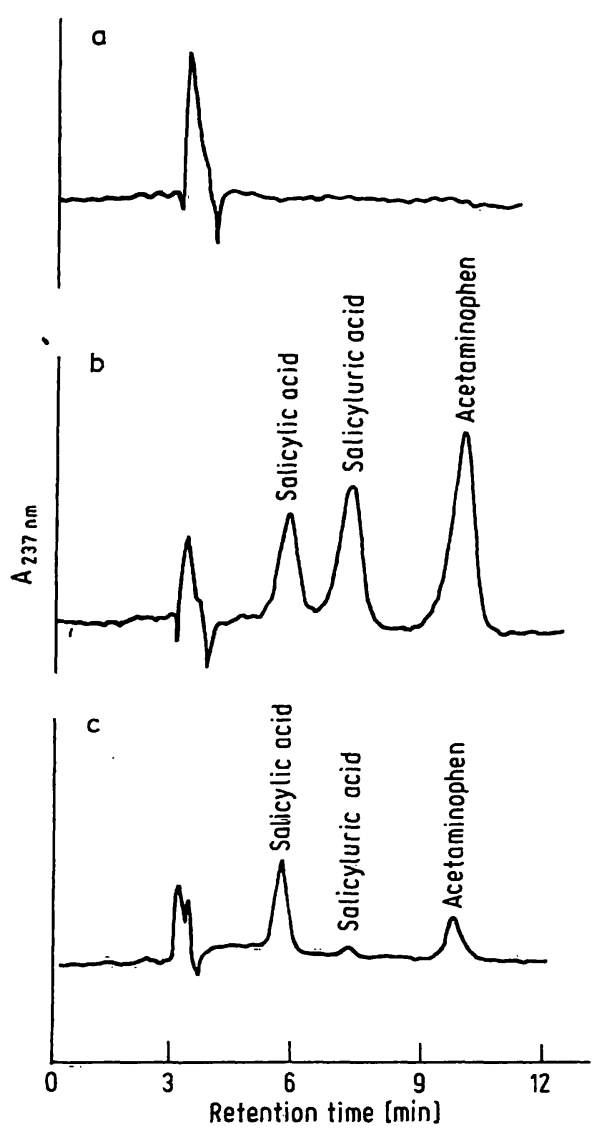

Fig. 2. High performance liquid chromatogram of human plasma extract: (a) blank plasma, (b) plasma spiked with $10 \mathrm{mg} / \mathrm{l}$ each of salicylic acid, salicyluric acid and acetaminophen and (c) human plasma sample 1.5 hour after $650 \mathrm{mg}$ aspirin ${ }^{\circledR}$ and 0.5 hour after the same dose of acetaminophen.

Tab. 5 . Absorbance and peak areas of $10 \mathrm{mg} / \mathrm{l}$ each of acetaminophen, salicylic acid and salicyluric acid at different wave lengths.

\begin{tabular}{|c|c|c|c|c|c|c|}
\hline \multirow[b]{2}{*}{$(\mathrm{nm})$} & \multicolumn{2}{|c|}{ Acetaminophen } & \multicolumn{2}{|c|}{ Salicylic acid } & \multicolumn{2}{|c|}{$\begin{array}{l}\text { Salicyluric } \\
\text { acid }\end{array}$} \\
\hline & $\begin{array}{l}\text { Absor- } \\
\text { bance }\end{array}$ & $\begin{array}{l}\text { Peak } \\
\text { area }\end{array}$ & $\begin{array}{l}\text { Absor- } \\
\text { bance }\end{array}$ & $\begin{array}{l}\text { Peak } \\
\text { area }\end{array}$ & $\begin{array}{l}\text { Absor- } \\
\text { bance }\end{array}$ & $\begin{array}{l}\text { Peak } \\
\text { area }\end{array}$ \\
\hline $\begin{array}{l}237 \\
250 \\
300\end{array}$ & $\begin{array}{l}0.025 \\
0.027 \\
0.003\end{array}$ & $\begin{array}{r}4294 \\
4309 \\
119\end{array}$ & $\begin{array}{l}0.014 \\
0.004 \\
0.009\end{array}$ & $\begin{array}{r}2050 \\
311 \\
1159\end{array}$ & $\begin{array}{l}0.016 \\
0.012 \\
0.008\end{array}$ & $\begin{array}{l}2473 \\
1934 \\
1152\end{array}$ \\
\hline
\end{tabular}


after the same dose for acetaminophen. Figure 3a shows a chromatogram of a human urine blank extracted at $\mathrm{pH} 5$. Figure $3 \mathrm{~b}$ illustrates the same standards added to drug-free urine and extracted. Figure $3 \mathrm{c}$ shows a chromatogram of a human urine sample $2 \mathrm{~h}$ after $650 \mathrm{mg}$ each of aspirin and acetaminophen. As shown, chromatograms from blank plasma yielded an extraneous peak around $3.5 \mathrm{~min}$, while chromatograms from blank urine produce peaks between 3.5 and $4.7 \mathrm{~min}$. None of these peaks showed any interference with the three compounds under study.
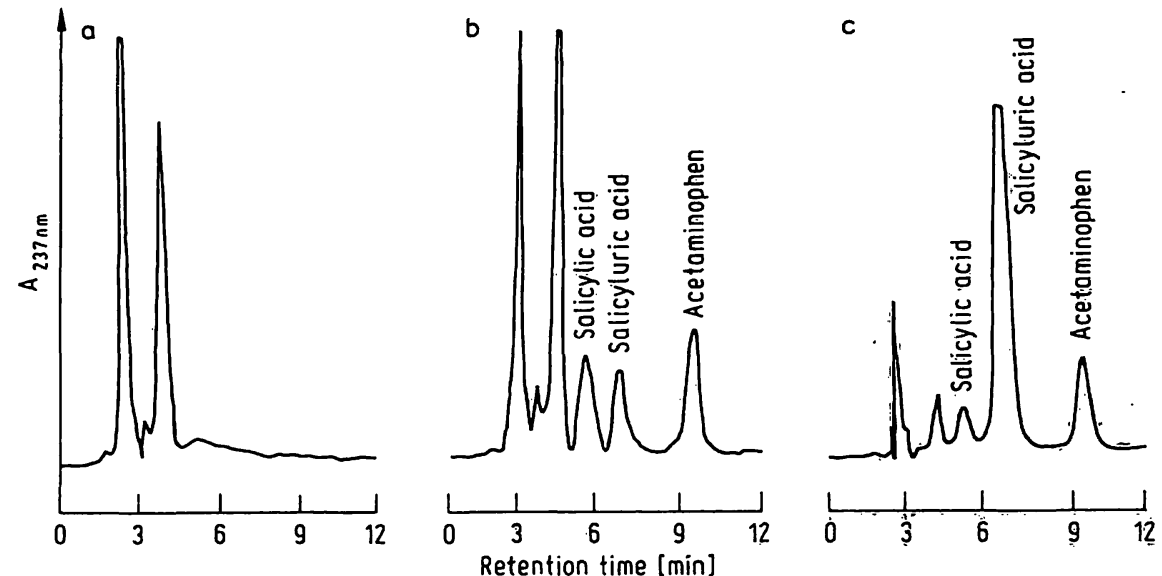

Fig. 3. High performance liquid chromatogram of human urine extract: (a) blank urine, (b) urine spiked with $10 \mathrm{mg} / 1 \mathrm{each}$ of salicylic acid, salicyluric acid and acetaminophen and (c) human urine sample 2.0 hours after 650 mg of aspirin ${ }^{\circledR}$ and 1.0 hour after the same dose of acetaminophen.

Accuracy and precision of this method for acetaminophen, salicylic acid and salicyluric acid in human plasma and urine are shown in tables 6 and 7. The three compounds were added to drug-free plasma and urine in concentrations ranging from 5 to $50 \mathrm{mg} / \mathrm{l}$ each and extracted as described before. The standard curves show a linear relationship between the concentrations. and peak areas over these ranges. The coefficient of variation of these results is less than $4 \%$ in all conncentrations studied. Concentrations lower or higher than this

Tab. 6. Recovery of acetaminophen, salicylic acid and salicyluric acid after extraction from plasma at pH 2. Coefficient of variation is less than $4 \%$ over these concentrations.

\begin{tabular}{|c|c|c|c|c|c|c|c|c|}
\hline \multirow{3}{*}{$\begin{array}{l}\text { Drug added } \\
(\mathrm{mg} / \mathrm{l})\end{array}$} & \multirow[t]{3}{*}{$\mathrm{N}$} & \multicolumn{2}{|c|}{ Acetaminophen } & \multicolumn{2}{|c|}{ Salicylic acid } & \multicolumn{3}{|c|}{ Salịcylựic agcidd } \\
\hline & & \multirow{2}{*}{$\begin{array}{l}\text { Drug } \\
\text { recovery } \\
(\mathrm{mg} / \mathrm{l})\end{array}$} & \multirow{2}{*}{$\begin{array}{l}\text { Recovery } \\
(\%), \bar{x} \pm s\end{array}$} & \multirow{2}{*}{$\begin{array}{l}\text { Drug } \\
\text { recoviery } \\
(\mathrm{mg} / \mathrm{l})\end{array}$} & Recovery & \multirow{2}{*}{$\begin{array}{l}\text { Drug } \\
\text { recọvery } \\
\text { (mg/l) }\end{array}$} & \multicolumn{2}{|c|}{ Recovery } \\
\hline & & & & & $(\%), \bar{x} \pm s$ & & $(\%), \bar{x}$ & $\pm s$ \\
\hline 5 & 10 & 4.8 & $96 \pm 3.2$ & 4.7 & $94 \pm 2.8$ & 4.8 & 96 & \pm 1.8 \\
\hline 10 & 10 & 9.8 & $98 \pm 0.65$ & 9.8 & $98 \pm 0.88$ & 10.4 & 104 & \pm 0.72 \\
\hline 20 & 10 & 19.6 & $98 \pm 1.2$ & 19 & $95 \pm 0.92$ & 20.2 & 101 & \pm 1.2 \\
\hline 30 & 10 & 28.8 & $96 \pm 0.89$ & 28.8 & $96 \pm 2.2$ & 28.9 & 96.4 & \pm 0.72 \\
\hline 40 & 10 & 41.6 & $104 \pm 1.5$ & 39.96 & $99.9 \pm 1.8$ & 40.4 & 101 & \pm 2.2 \\
\hline 50 & 10 & 48 & $96 \pm 2.4$ & 48.2 & $96.3 \pm 2.7$ & 51.5 & 103 & \pm 1.8 \\
\hline
\end{tabular}

Tab. 7. Recovery of acetaminophen, salicylic acid and salicyluric acid after extraction from urine at pH 5 . Coefficient of variation is less than $4 \%$ over these concentrations.

\begin{tabular}{|c|c|c|c|c|c|c|c|}
\hline \multirow{2}{*}{$\begin{array}{l}\text { Drug } \\
\text { added }\end{array}$} & \multirow[t]{2}{*}{$\mathrm{N}$} & \multicolumn{2}{|c|}{ Acetaminophen } & \multicolumn{2}{|c|}{ Salicylic acid } & \multicolumn{2}{|c|}{ Salicyluric acid } \\
\hline & & $\begin{array}{l}\text { Drug } \\
\text { recovered } \\
(\mathrm{mg} / \mathrm{l})\end{array}$ & $\begin{array}{l}\text { Reccovery } \\
(\%), \bar{x} \pm s\end{array}$ & $\begin{array}{l}\text { Drug } \\
\text { recovered } \\
(\mathrm{mg} / \mathrm{l})\end{array}$ & $\begin{array}{l}\text { Reçovery } \\
(\%), \bar{x} \pm s\end{array}$ & $\begin{array}{l}\text { Drug } \\
\text { recovered } \\
(\mathrm{mg} / \mathrm{l}) \\
\end{array}$ & $\begin{array}{l}\text { Recovery } \\
(\%), \bar{x} \pm s\end{array}$ \\
\hline $\begin{array}{r}5 \\
10 \\
20 \\
30 \\
40 \\
50\end{array}$ & $\begin{array}{l}10 \\
10 \\
10 \\
10 \\
10 \\
10\end{array}$ & $\begin{array}{r}4.9 \\
9.8 \\
19.5 \\
28.9 \\
39.8 \\
47\end{array}$ & $\begin{array}{l}98 \pm 2.8 \\
98 \pm 0.74 \\
97.6 \pm 1.8 \\
96.3 \pm 1.2 \\
99.5 \pm 1.9 \\
94 \quad \pm 2.8\end{array}$ & $\begin{array}{l}4.4 \\
8.8 \\
17.6 \\
25.5 \\
34.8 \\
43\end{array}$ & $\begin{array}{l}87 \pm 3.2 \\
88 \pm 1.2 \\
88 \pm 2.2 \\
85 \pm 1.8 \\
87 \pm 1.2 \\
86 \pm 2.1\end{array}$ & $\begin{array}{l}4.45 \\
8.8 \\
1.7 .4 \\
26.1 \\
34.4 \\
43 .\end{array}$ & $\begin{array}{l}89 \pm 2.8 \\
88 \pm 0 \div 92 \\
87 \pm 1.8 \\
87 \pm 1.2 \\
86 \pm 1.2 \\
86 \pm 1.9\end{array}$ \\
\hline
\end{tabular}


range can be estimated with the same efficiency by changing the sample or methanol volumes or by changing the UV detector sensitivity.

This method was used to study the urinary excretion in $24 \mathrm{~h}$ of free acetaminophen, salicylic acid and salicyluric acid in two healthy human volunteers who ingested $650 \mathrm{mg}$ of aspirin ${ }^{\circledR}$ followed $1 \mathrm{~h}$ later by $650 \mathrm{mg}$ of acetaminophen. Figure 4 illustrates the excretion of the three compounds in $\mathrm{g} / \mathrm{l}$ at various times. As shown, acetaminophen concentration in urine was at its highest level 1-2 hours after drug administration. Salicylic acid and salicyluric acid reached their highest concentration level within 3 to 4 hours following drug administration. From this study we observed that the amount of free acetaminophen excreted in 24 hours accounts for 3.6 to $4.5 \%$ of acetaminophen dose. Salicylic acid accounts for 6.2 to $9.5 \%$ of the aspirin ${ }^{\circledR}$ dose while salicyluric acid excretion accounts for 59 to $60 \%$ of the aspirin ${ }^{\circledR}$ dose. These figures agree with other reports $(5,23)$.
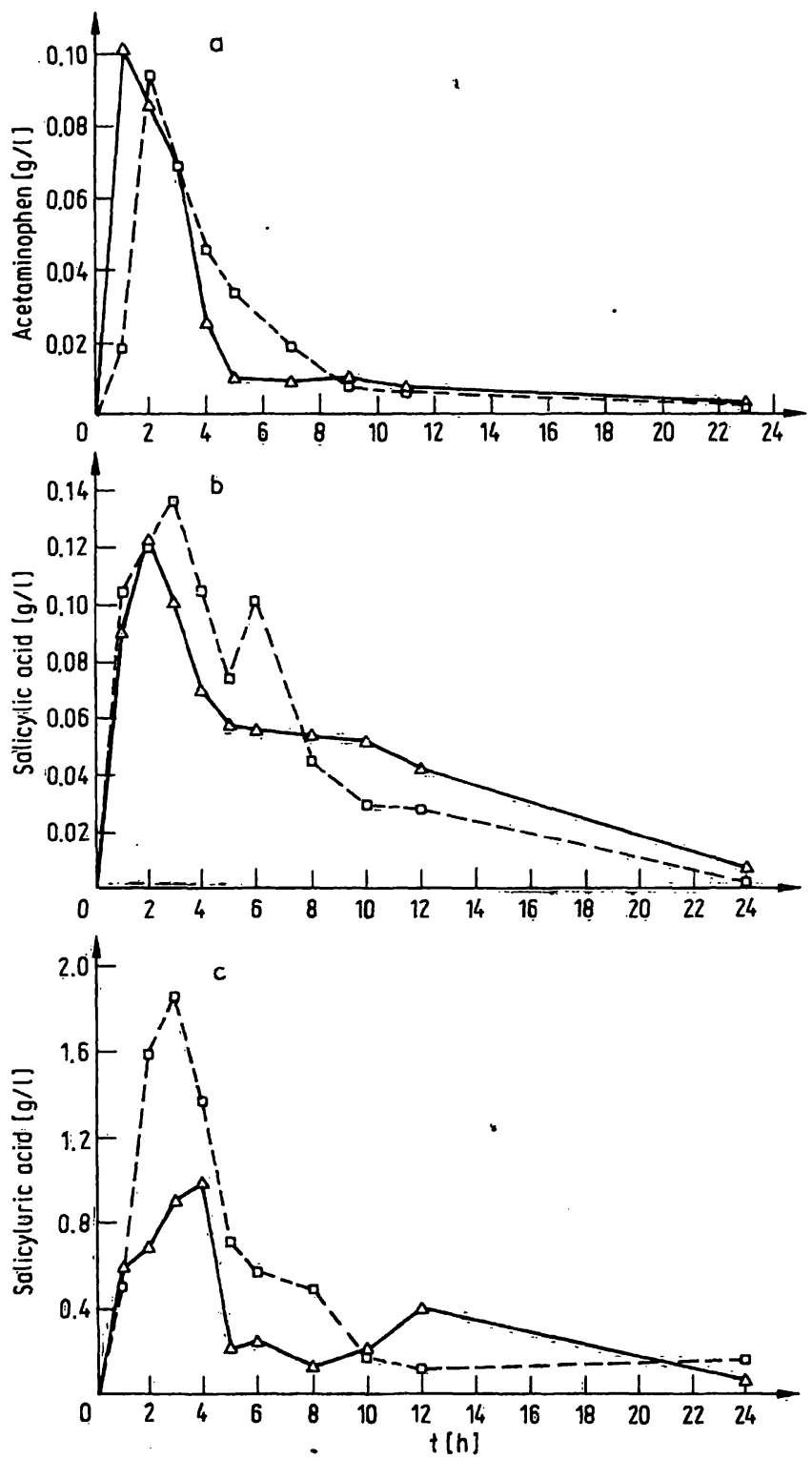

Fig. 4. Twenty-four hour excretion of acetaminophen (a), salicylic acid (b) and salicyluric acid (c) in two human subjects after a single dose $(650 \mathrm{mg})$ each of aspirin ${ }^{\circledR}$ and acetaminophen.
This method was also used to study the plasma concentrations of the three compounds for the same volunteers who ingested the previous doses of both aspirin ${ }^{\circledR}$ and acetaminophen. Blood samples were collected every $15 \mathrm{~min}$ to 1 hour up to 4 hours following drug administration. Figure 5 illustrates the plasma concentration versus time of each compound. As shown, the highest plasma concentration of acetaminophen which is $11 \mathrm{mg} / \mathrm{l}$ was obtained 0.5 hour after drug administration. Salicylic acid and salicyluric acid have their highest plasma concentrations $(35 \mathrm{mg} / \mathrm{l}$ and $2.8 \mathrm{mg} / \mathrm{l}$ respectively) about 1.5 hour after oral aspirin ${ }^{\circledR}$ administration. The plasma concentrations of the three compounds over 4 hours in our study are in agreement with results presented by Levy et al. (24).

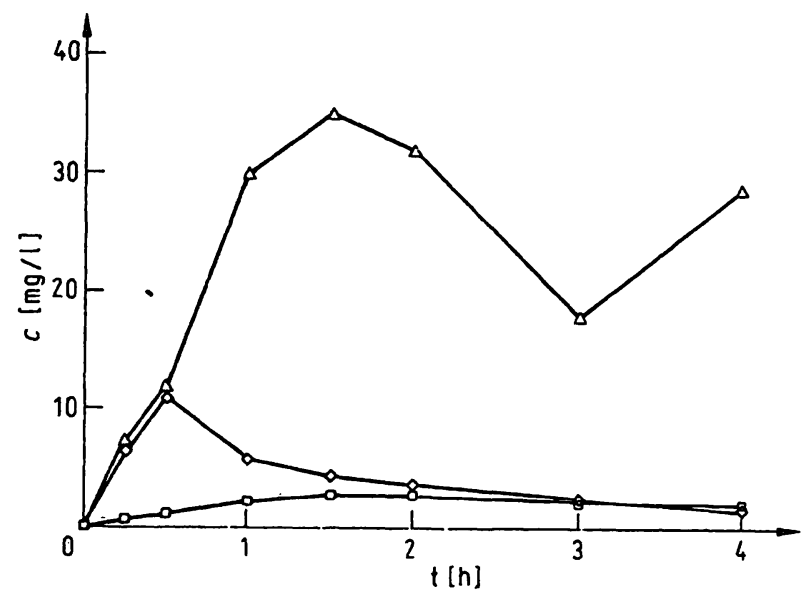

Fig. 5. Plasma concentration of, salicylic acid $\Delta-\Delta$, salicyluric acid $\diamond-\diamond$ and acetaminophen $\square-\square$ over four hours after a single dose $(650 \mathrm{mg})$. each of aspirin ${ }^{\circledR}$ and acetaminophen.

In summary, this HPLC method is simple and reliable for determination and quantitation of acetaminophen, salicylic acid and salicyluric acid in biological fluids. This method is highly sensitive and can detect and quantitate each of the three compounds in a concentration up to $1 \mathrm{mg} / \mathrm{l}$. The three compounds can be extracted by one solvent and separated during one run in HPLC. A single run lasts only for 15 minutes. This method can also be used for determination of other salicylates and acètaminophen metabolites after acid or enzymatic hydrolysis of these conjugates to the free compound $(2,21)$. We are currently using this method for pharmacökinetic and pharmacodynamic studies of a combination of acetaminophen and salicylates in human.

\section{Acknowledgments}

The authors would like to thank Mr. Herbert Farrish and staff members of the Chemical Pathology Laboratory for their cooperation and technical assistance and Mrs. Rüth Buffington for her excellent assistance in preparation of this manuscript. The authors are also indebted to Mr. Ronald Tisdell and staff members of the Poison Control Center at Galveston, Texas for their valuable participation in preparation of the subject of this work. 


\section{References}

1. Houston, J. B. \& Levy, G. (1976) J. Pharm. Sci. 65, 12181221.

2. Levy, G. \& Yamada, H. (1971) J. Pharm. Sci. 60, 215-221.

3. Mitchell, J. R., Thorgeirsson, S. S., Potter, W. Z., Jollow, D. J. \& Keiser, H. (1974) Clin. Pharmacol. Ther. 16, 676-684.

4. Bickers, R. G. \& Roberts, R. J. (1979) J: Pediat. 94, 10011003.

5. Levy, G. \& Regardh, C. G. (1971) J. Pharm. Sci. 60, 608611.

6. Miceli, J. N., Arvanid, M. K. \& Done, A. K. (1979) Pediatrics $63,609-611$.

7. Trinder, P. (1954) Biochem. J. 57, 301-303.

8. Prescott, L. F. (1971) J. Pharm. Pharmacol. 23, 807-808.

9. Amsel, L. P. \& Davison, C. (1967) J. Pharm. Sci. 61, 14741475.

10. Rowland, M. \& Riegelman, S. (1967) J. Pharm. Sci. 56, 717-720.

11. Ramachander, G., Williams, F. D. \& Emele, J. F. (1973) J. Pharm. Sci. 62, 1498-1500.

12. Wong, L. T., Solomonraj, G. \& Thomas, B. H. (1976) J. Pharm. Sci. 65, 1064-1066.

13. Horvitz, R. A. \& Jatlow, P. I. (1977) Clin. Chem. 23, $1596-1598$
14. Blair, D. \& Rumack, B. H. (1977) Cliñ. Chem. 23, 743745.

15. Blair, D., Rumack, B. H. \& Peterson, R. G: (1978) Clin. Chem. 24, 1543-1544.

16. Peng, G. W., Gadalla, M. A. F., Smith, V. Chiou, W. L. (1978) J. Pharm. Sci. 67, 710 $=712$.

17. Harrison, L. I., Funk, M. L. \& Ober, R. E. (1980) J. Pharm. Sci. 69, 1268-1271.

18. Ascione, P. P. \& Chrekian, G. P. (1975) J. Pharm. Sci. 64, 1029-1033.

19. Altmiller, D. H. \& Fowler, M. W. (1977) Clin. Chem. 23, 1138.

20. Miceli, J. N., Aravind, M. K., Cohen, S. N. \& Done, A. K. (1979) Clin. Chem: 25, 1002-1004.

21. Levy, G. \& Procknal, J. A. (1968) J. Pharm. Sci. 57, 13301335 .

22. Buckpitt, A. R., Rollins, D. E., Nelsọn, S. D., Franklin, R. B. \& Mitchell, J. R. (1977) Anal. Biochem. 83, 168-177.

23. Levy, G. (1965) J. Pharm. Sci. 54, 959-967.

24. Bhath, M. C., Shaw, S. M., Christian, J. E. \& Miya, T. S. (1969) J. Pharm. Sci. 58, 503-504.

Dr. Ahmed E. Ahmed Associate Professor Department of Pathology The University of Texas Medical Branch at Galveston Galveston, Texas 77550 U.S.A. 